\title{
BIOGEOCHEMICAL SIGNIFICANCE OF EDDIES OF THE EASTERN ARABIAN SEA
}

\author{
REJOMON, G.* - DINESH KUMAR, P.K. - NAIR, M. \\ National Institute of Oceanography (CSIR), \\ Regional Centre, Kochi-18, India \\ (phone: +91-484-2390814; fax: +91-484-2390618) \\ *Corresponding author \\ e-mail:grejomon@yahoo.com \\ (Received $15^{\text {th }}$ September 2011; accepted $29^{\text {th }}$ January 2013)
}

\begin{abstract}
Within the Arabian Sea, the western part is considered to be highly productive when compared to the northern, central and eastern parts of the basin. Despite the contrasting chlorophyll and primary productivity patterns, sediment trap data show that annual fluxes of organic carbon reach comparable rates in most regions of this highly productive basin. The traditional mechanisms of nutrient supply to the upper ocean waters of the Arabian Sea cannot only account for this. Episodic injections of nutrients associated with cold-core eddies stimulate rapid biological activity and increase biological production in the open ocean waters of the eastern Arabian Sea during the demise of the southwest monsoon. In addition to wind-driven coastal upwelling during the monsoons, annually, an eddy-mediated enhanced biological production, at regional to basin-wide scales is proposed. The enhanced production caused by a high nutrient supply mechanism such as a meso-scale eddy leads directly to organic carbon fluxes to the deep Arabian Sea. The elevated export flux occurred in association with the rapid response of grazers was imported to the deeper layers which leads to a spectacular enhancement of biogenic particle sedimentation.
\end{abstract}

Keywords: Arabian Sea, nutrients, eddies, primary productivity, chlorophyll a

\section{Introduction}

The Arabian Sea, situated in the northwest Indian Ocean, is traditionally considered to be a region of higher biological production compared to its eastern counterpart, the Bay of Bengal. Within the Arabian Sea, the area off Somalia is considered to be the most productive compared to the northern, central, and eastern parts of the basin. One of the major climatic features of the southern Asian continent is the summer monsoon, which affects the entire Arabian Sea and the adjacent land masses from June to September, which in turn induces organic carbon fluxes in the eastern Arabian Sea and hence plays a major role in the semiannual pattern of particle fluxes to the deep Arabian Sea basin (Nair et al., 1989). It is worth noting that sediment trap studies and satellitebased chlorophyll pigment distributions indicate that primary productivity in the northern Arabian Sea during summer monsoon is considerably higher than in the eastern Arabian Sea (Ittekkot et al., 1992; Antoine et al., 1996). Furthermore, primary productivity measurements made by different authors (Koblentz-Mishke et al., 1970; Krey and Babenard, 1976), as well as satellite-derived chlorophyll charts (Brock et al., 1991; Brock and McClain, 1992; Lierheimer and Banse, 2002), indicated that primary productivity and chlorophyll concentrations in the western Arabian Sea are more than double those of the central and eastern Arabian Sea. However, despite the contrasting chlorophyll and productivity pattern, the average annual fluxes of organic carbon reach comparable magnitudes in most regions of the Arabian Sea basin (Haake et al., 1993). 
The seasonal reversal of winds associated with monsoons leads to strong seasonal upwelling of nutrient-rich water from depths along the shelf waters resulting in a high surface productivity, but this alone is inadequate for a regional wise comparison of average annual export particle fluxes from the euphotic zone of the Arabian Sea basin (Sen Gupta and Naqvi, 1984; Haake et al., 1993). Indeed, the traditional nutrient supply mechanisms to the surface layers of the region include wind-induced deeper mixing, wind-driven coastal upwelling, open-ocean upwelling driven by Ekman pumping and lateral advection etc, only cannot account for this (Luis and Kawamura, 2004; Wiggert et al., 2005). Interestingly, with the transition from southwest monsoon to fall intermonsoon, the upward Ekman pumping in the southwest coast of India is still increasing due a combined effect of alongshore wind stress and remote forcing in the form of coastally trapped Kelvin waves and offshore-propagating Rossby waves (Vinayachandran and Yamagata, 1998; Smitha et al., 2008). Nevertheless, eddies, which are ubiquitous features throughout the world oceans (Ediger et al. 2005; Whitney et al., 2005; Marra and Barber, 2005; Wiggert et al., 2005), their role in enhancing the biological productivity of the eastern Arabian Sea was not addressed despite its considerable evidence exists from the eddy-resolving models (Bruce et al., 1994; Mc Creary et al., 1996; Shankar and Shetye, 1997; Bruce et al., 1998). These episodic phenomena are likely significant mechanisms for the transport of large amounts of new nitrogen to the euphotic zone and result in enhanced rates of primary production and export. However, the biogeochemical significance of eddies and its spatial and temporal variability of the eastern Arabian Sea has remained vague, enigmatic and controversial (Wiggert et al., 2005). The present study attempts to address the role of eddies in enhancing the biological productivity of the eastern Arabian Sea during southwest monsoon retreat and its impact on annual organic carbon fluxes to the deep Arabian Sea.

\section{Materials and methods}

This study is based on data collected during Cruise No. 217 of Fisheries and Oceanographic Research Vessel (FORV) Sagar Sampada during September $14^{\text {th }}-$ October $18^{\text {th }}, 2003$, under the Marine Research-Living Resource Programme, covering the open ocean waters along the western margin of the sea off the West Coast of India (Fig. 1). Water samples were collected from standard depths (Surface, 10, 20, 30, 50, 75, 100, 150, 200, 300, 500, 750 and $1000 \mathrm{~m}$ ), using a PVC-coated stainless steel SeaBird Electronics CTD Rosette Sampler fitted with precleaned 1.8 litre Teflon coated Go-Flo bottles (General Oceanics). A Sea Bird CTD collected temperature-salinity profiles. Surface meteorological variables were measured every 10 minutes using the shipboard Integrated Data Acquisition Software (IDAS) system. Dissolved oxygen was measured by Winkler titrations. Nitrate was analysed onboard immediately after the collection using a Skalar Segmented Flow Auto Analyzer (Model SA-1050). For Primary Productivity (PP) and chlorophyll $a$ measurements, water samples were collected from seven depths (Surface, 10, 20, 50, 75, 100 and $120 \mathrm{~m}$ ), using a PVCcoated stainless steel CTD-rosette sampler with precleaned 5-litre Teflon coated Go-Flo bottles (General Oceanics). Primary production was measured by in-situ incubation using the ${ }^{14} \mathrm{C}$-technique for 12 hours during day time (U. N. Educational, Scientific and Cultural Organization (UNESCO), 1994). For chlorophyll measurements, one liter of seawater was collected from the standard depths and filtered through GF/F (nominal 
pore size $0.7 \mu \mathrm{m})$ filters and Chlorophyll $a$ was estimated spectrophotometrically (Perkin-Elmer UV/Vis) using $10 \mathrm{ml}$ of $90 \%$ acetone (Strickland and Parsons, 1972).

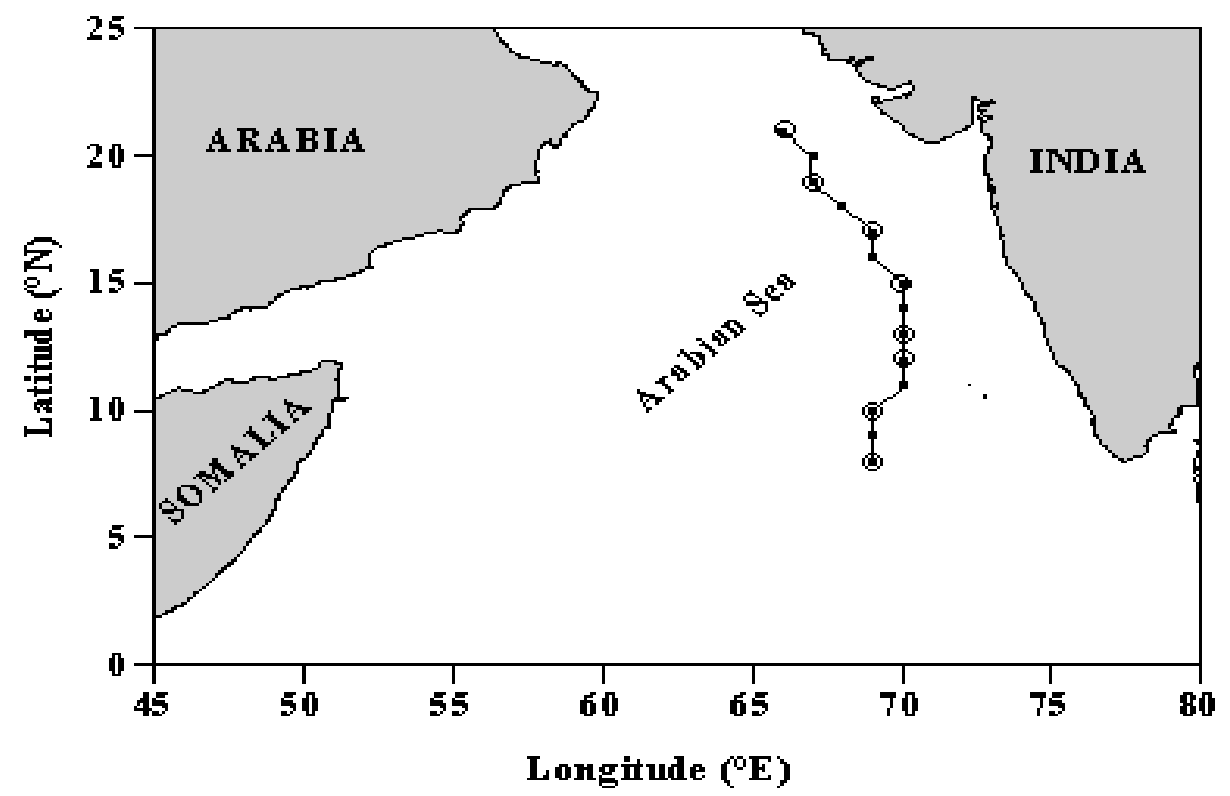

Figure 1. Map of the study area with station locations. Stations where temperature, salinity, dissolved oxygen and nitrate were measured are shown as dark circles where as stations where biological measurements were also done are shown as open circles

\section{Results and discussion}

Thermal structure along the open ocean transect showed the presence of two subsurface cold-core eddies of comparable magnitude and variable strength (Fig. 2a). Among the two cold-core eddies present at the open ocean transect, one had a diameter of approximately $240 \mathrm{~km}$ at the $17{ }^{\circ} \mathrm{C}$ isotherm, and for the other, the diameter was approximately $480 \mathrm{~km}$ at the $15{ }^{\circ} \mathrm{C}$ isotherm. The first eddy extended to a depth of about $100 \mathrm{~m}$ while the second extended to a depth of $200 \mathrm{~m}$. The center of the first eddy was between $8^{\circ} \mathrm{N}$ and $12^{\circ} \mathrm{N}$ while the center of the second was between $13^{\circ} \mathrm{N}$ and $17^{\circ} \mathrm{N}$. A shallowing of isotherms was noticed between $8^{\circ} \mathrm{N}$ and $12^{\circ} \mathrm{N}$ and then deepening, followed by a shallowing of isotherms between $13^{\circ} \mathrm{N}$ and $17^{\circ} \mathrm{N}$, while north of it the isotherms shoaled towards $21^{\circ} \mathrm{N}$. In the former case the $28{ }^{\circ} \mathrm{C}$ isotherm shoaled from 30 to $10 \mathrm{~m}$, and thus the upper thermocline showed a vertical displacement of $20 \mathrm{~m}$, which tapered off towards the lower thermocline. Both eddies showed a vertical displacement of $20 \mathrm{~m}$ which, for both, tapered off towards the bottom of the thermocline. This was clearly a signature of a cold-core eddy, seen below $10 \mathrm{~m}$ depth, which lowered the ambient temperature at $40 \mathrm{~m}\left(27^{\circ} \mathrm{C}\right)$ by about $4{ }^{\circ} \mathrm{C}$. A warm surface layer $\left(\geq 29^{\circ} \mathrm{C}\right.$ isotherm), which extended to a depth of $\sim 30 \mathrm{~m}$, lies over the two eddies. Over northern feature $29{ }^{\circ} \mathrm{C}$ waters extend down to $\sim 20 \mathrm{~m}$ but over the southern feature, temperatures are $<29^{\circ} \mathrm{C}$. The horizontal variability in this layer was small over the eddy core region compared to that of the exterior frontal structure, which partially surrounded the eddy system. Outside this region thermal fronts were found on either side of the eddy, which was weak in the north and strong in the south. 
The salinity structure showed strikingly similar features as that of temperature. For example, within the region of the eddy system, isotherms and isohalines exhibited a concave structure. The salinity structure showed strong gradients in the upper $100 \mathrm{~m}$, followed by almost homogenous waters down to $1000 \mathrm{~m}$ (shown only up to $200 \mathrm{~m}$; Fig.2b). In addition, the small-scale haline fronts that partially surround the eddy were more intense than the corresponding thermal fronts. Furthermore, the haline fronts were strongest in the southern region and weak in the northern region of both eddies. The decrease in salinity front in the upper $20 \mathrm{~m}$ at $8^{\circ} \mathrm{N}$ to $11^{\circ} \mathrm{N}$ and $15^{\circ} \mathrm{N}$ to $17^{\circ} \mathrm{N}$ is probably due to entrapment of low saline waters from the Lakshadweep Low (LL) region (Shankar and Shetye, 1997), whereas a downward tongue-like vertical projection of $36.6 \mathrm{psu}$ high saline water at the upper $50 \mathrm{~m}$ centered in the middle-outer portion of the two eddies is attributed to the entrapment of Arabian Sea high salinity waters (ASHSW) from the northern Arabian Sea by the equatorward surface currents (Shetye et al., 1990).

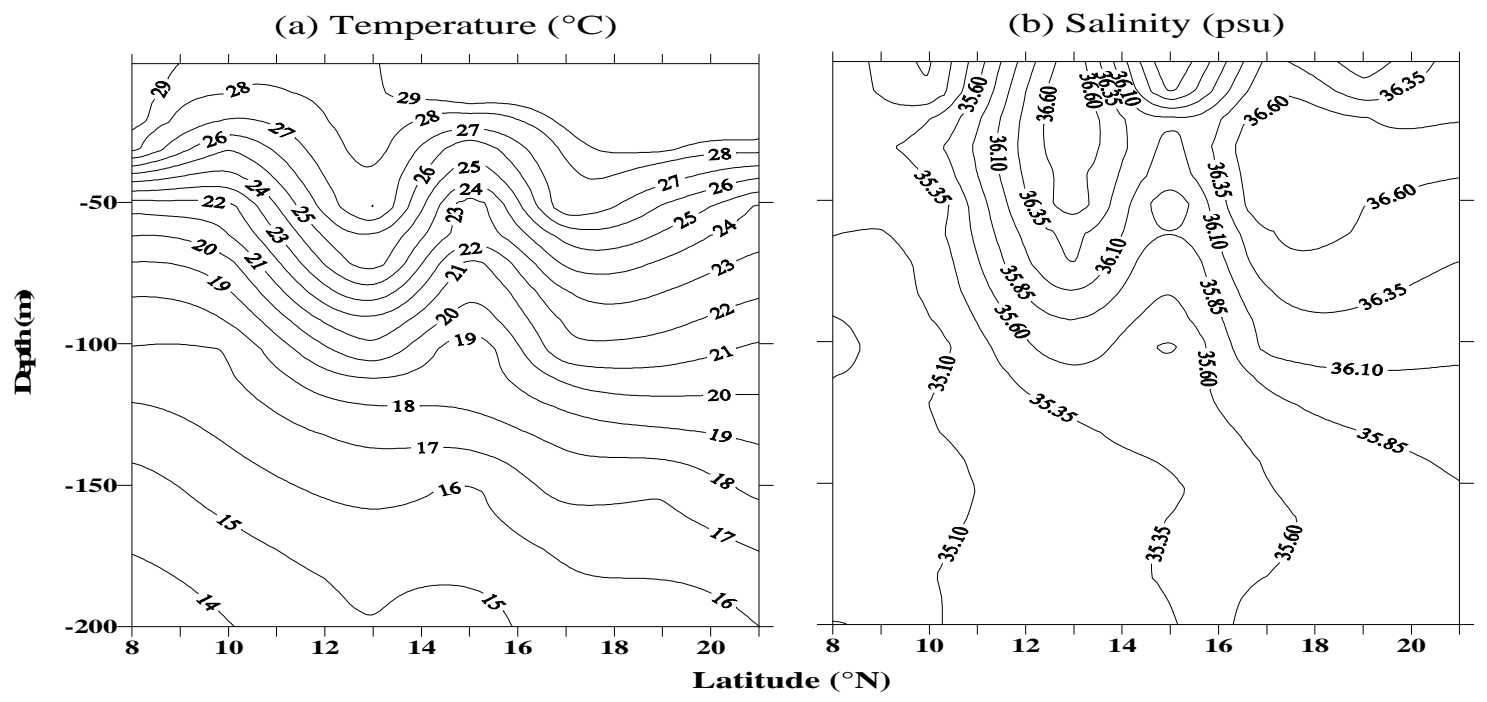

Figure 2. Vertical section of (a) temperature $\left({ }^{\circ} \mathrm{C}\right)$ and (b) salinity (psu) in the upper $200 \mathrm{~m}$ along the open ocean transect of the eastern Arabian Sea

Pronounced nitrate fronts, spatially aligned with the strong thermal fronts were present in the north and south quadrant of the two-eddy system (Fig. 3b). Strong nitrate fronts were present in the southern side of the two-eddy system but were weak on the northern side. Interestingly the temperature contours $\left(29^{\circ} \mathrm{C}\right)$ and isoline of $2.0 \mu \mathrm{M}$ of nitrate south of the two eddies shoaled upwards to the surface. The cores of two coldcore eddies were characterized by low temperature $\left(<27^{\circ} \mathrm{C}\right)$, low dissolved oxygen $(<$ $100 \mu \mathrm{M})$ and high nitrate $(>10 \mu \mathrm{M})$ at $30 \mathrm{~m}$. The location and strength of the nitrate front were consistent with the isotherms of temperature and isohalines of salinity, which showed that water of deep oceanic origin, was preferentially entrained into the upper surface levels. The physical fronts showed uniformity of structure and intensity to the surface consistent with the isolines of nitrate, which had pronounced nitrate concentrations in the center of the cold-core region.

The position of the eddies can be understood in the context of basin-scale circulation. During the onset of the summer monsoon, a low-pressure area is developed over central 
Asia, causing a persistent wind system blowing from the south-west and bringing about a spectacular reversal of the upper ocean circulation (Shankar et al., 2002), which is further developed into a relatively strong southerly current that brings comparatively ASHSW southwards at the surface layers along the sea off the West Coast of India (Shetye et al., 1990). Further, during this time of the year, the Indian summer monsoon current (SMC) flows eastward as a continuous current from the western Arabian Sea to the Bay of Bengal (Vinayachandran et al., 1999). The bulging of the northern salinity isoline (36.6 psu) towards south suggests the presence of equatorward surface current and the presence of $>36$ psu salinity at the core of the northern eddy, which lends further support to the advection of ASHSW into the southern part of the open ocean waters of the West Coast of India. The hydrological imbalance thus created by the net southward and eastward surface flow, is further counter-balanced by a cyclonic poleward undercurrent confirmed by the salinity bulges towards north in the subsurface (100-200 m). When the cyclonically propagating southern and northern eddy are embedded in an equatorward surface current and strong eastward monsoon current, the strong eastward monsoon current will augment the southward propagation of the southern eddy whereas the equatorward surface current will augment the northward propagation of the northern eddy. The stronger/weaker eastward propagation of the southern and northern eddies is further augmented or counteracted by the MaldiveLaccadive Island chain and Ekman drift at the southwest coast of India (Shetye et al., 1990). The upward/downward tilt of isotherms in the eddy region is associated with equatorward/poleward moving undercurrents.

(a) Dissolved oxygen $(\mu \mathrm{M})$

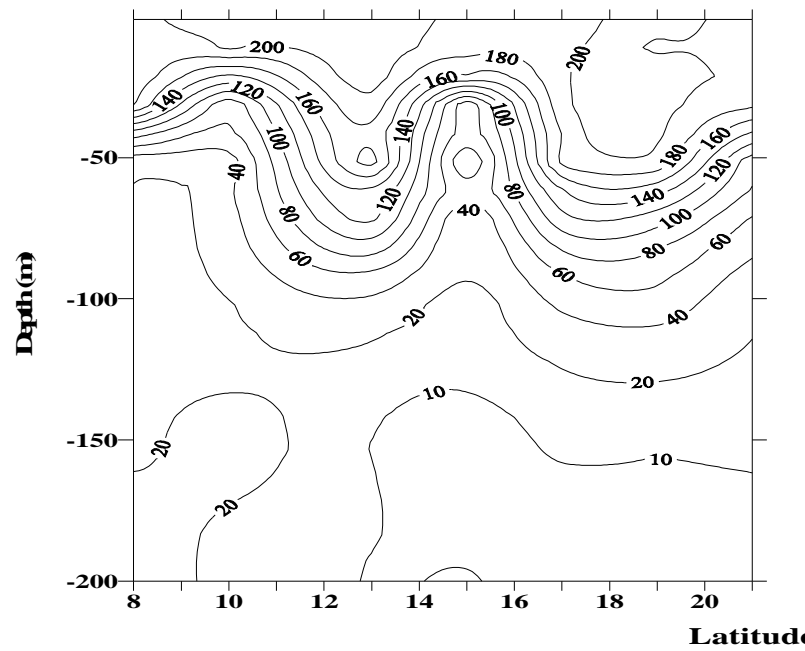

(b) Nitrate $(\mu \mathrm{M})$

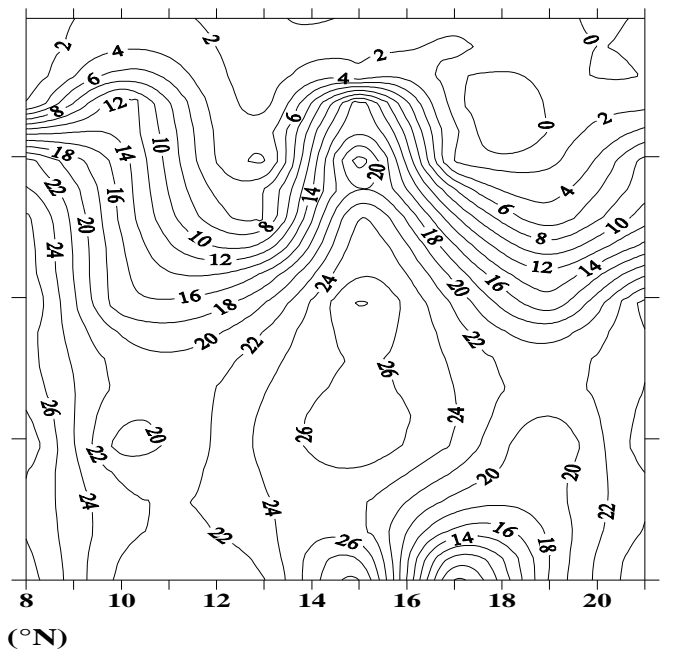

Figure 3. Vertical section of (a) dissolved oxygen $(\mu M)$ and $(b)$ nitrate $(\mu M)$ in the upper 200 malong the open ocean transect of the eastern Arabian Sea

Thus, from the hydrographic data, we infer the presence of two subsurface cold-core eddies in the eastern Arabian Sea during the southwest monsoon retreat. The one-degree drop of temperature towards the southern latitudes along the open ocean combined with shoaling of isotherms indicated active eddy mixing in the southwestern open ocean waters. The southward extension of the isotherms/isohalines $\left(29^{\circ} \mathrm{C} / 36.6 \mathrm{psu}\right)$ from the north at $\sim 30 \mathrm{~m}$ depth showed the spreading of warm Arabian Sea high Salinity waters 
towards the south along the open ocean. The strong stratification of the upper ocean by the warm and high salinity waters inhibited the surfacing of the doming isopleths of the northern eddy and confined it below $20 \mathrm{~m}$ depth.

A significant feature observed from the thermal structure was the presence of thermocline oscillations and cold-core eddy signatures of varying magnitudes and strengths. Under the interaction of two counter-rotating eddies, cold waters enriched in nutrients were pumped into the surface layers. Consistent with the southward shoaling of isotherms and isohalines of two eddies in the open-ocean section; nitrate isopleths also showed shoaling. The cyclonic circulation associated with the cold-core eddy is capable of pumping nutrient-rich deeper waters into the euphotic zone, as was evident from the doming up of nitrate isopleths. Thus both eddies and shoaling of isotherms were induced by a favourable southwesterly wind, which lead to surfacing of nutrients.

Eddies within the eastern Arabian Sea are not only causing the replenishment of nutrients from depth, but also lead to the formation a broad oxygen minimum zone $\left[\mathrm{O}_{2}\right.$ $\sim 20 \mu \mathrm{M}$ ] with its increasing thickness from the northwest to southwest open ocean waters. The oxygen minimum zone $\left[\mathrm{O}_{2} \sim 20 \mu \mathrm{M}\right]$ shoals upwards from north to south under the influence of eddies. Oxygen anomalies within in the eddy cores are suggestive of significant carbon export events. The source of the organic matter supporting oxygen consumption at intermediate depths has been assumed to be vertically sinking biogenic particles, but contributions from horizontally advected organic material also have been suggested for this region (Dileepkumar et al., 1990). Thus the high organic production in the surface layers together with slow renewal of waters within the ventillated subsurface layers of eddies, results in an over-consumption of oxygen at intermediate depths which leads to the development of an intense deep oxygen minimum layer. This depresses mid-water recycling of the organic matter allowing much more detrital material to sink to great depths without being recycled by the mid-water consumers (Angel, 1984), resulting in an enhanced flux of labile organic material to the deep-sea sediment traps of the Arabian Sea.

Concomitant with the nitrate introduced to the surface by eddy mixing, the chlorophyll $a$ showed enhanced concentrations generally coinciding with the location of eddies. During this period, the surface primary production and chlorophyll $a$ of the open ocean transect varied from 2.0 to $8.4 \mathrm{mg} \mathrm{C} / \mathrm{m}^{3} /$ day (average $6.0 \mathrm{mg} \mathrm{C} / \mathrm{m}^{3} /$ day) and from 0.03 to $0.38 \mathrm{mg} / \mathrm{m}^{3}$ (average $0.22 \mathrm{mg} / \mathrm{m}^{3}$ ), respectively. The vertical sections of chlorophyll $a$ in general show two maxima as rings - the first one between 20-30 m depth $\left(\sim 0.35 \mathrm{mgC} / \mathrm{m}^{3}\right)$ centered at $10^{\circ} \mathrm{N}$, and the second one between $50-75 \mathrm{~m}$ depth $(\sim$ $0.30 \mathrm{mg} \mathrm{C} / \mathrm{m}^{3}$ ) centered at $19^{\circ} \mathrm{N}$. The subsurface chlorophyll $a$ maximum encounted at $19^{\circ} \mathrm{N}$ is associated with the nitracline $(\sim 50 \mathrm{~m})$. The spatial variations of primary productivity and chlorophyll $a$ showed that maximum pigments $\left(8.4 \mathrm{mg} \mathrm{C} / \mathrm{m}^{3} / \mathrm{day} \&\right.$ $0.38 \mathrm{mg} \mathrm{C} / \mathrm{m}^{3} /$ day) are likely to be located along the frontal zone adjacent to the center of the first eddy and near the center of the upper portions of the cold core region (Fig. 4). The cyclonic circulation of the eddy pumps nutrients, which in turn triggers the new production and leads to enhanced levels of chlorophyll $a$ concentrations. Cold core eddies in the Eastern Tropical Pacific are found to enhance the supply of nitrate into the euphotic zone which, in turn, is rapidly utilized by phytoplankton, enhancing primary production and chlorophyll levels in the vicinity of the upper portions of the cold-core region (King, 1986; Platt et al., 1989). The importance of eddies and related open ocean upwelling on primary productivity has been recognized by many other workers (Wiggert et al., 2005; Ediger et al., 2005; Whitney et al., 2005), and has been indicated 
as a source of nutrients in the western Arabian Sea (Marra and Barber, 2005). An integrated (down to $120 \mathrm{~m}$ ) chlorophyll a concentration of $30.2 \mathrm{mg} \mathrm{C} / \mathrm{m}^{2} / \mathrm{day}$ and primary production of $490 \mathrm{mg} \mathrm{C} / \mathrm{m}^{2} /$ day at $10^{\circ} \mathrm{N}$ in the vicinity of the southern eddy is observed in the present study, which is more than double the value outside the eddy region $\left(13.2 \mathrm{mgC} / \mathrm{m}^{2} /\right.$ day and $200 \mathrm{mg} \mathrm{C} / \mathrm{m}^{2} /$ day at $21^{\circ} \mathrm{N}$ ). Prasannakumar et al. (2004) also noted an enhancement of primary productivity of 2 to 8 times in the eddy-mixing zone when compared to the non-eddy regions of the Bay of Bengal during summer monsoon. The chlorophyll distribution at $10^{\circ} \mathrm{N}$ showed a primary productivity maximum, which is a characteristic of eutrophic upper ocean whereas at $19^{\circ} \mathrm{N}$ it showed a deep chlorophyll $a$ maxima typical of the oligotrophic upper ocean due to significant variations in the strength of vertical mixing. The deep chlorophyll $a$ maximum observed was strongly linked to the upper-ocean stratification which appears to a prominent source of export production and is quite similar to that depicted by Bhattathiri et al. (1996) for the eastern Arabian Sea. From the vertical thermal structure it can be inferred that a warm layer covering the upper portions of the northern eddy is more intense than the southern eddy and it extends to depth of $\sim 40 \mathrm{~m}$, leading to more stratified, thermally stable oligotropic waters, due to high subsurface advection of warm Arabian Sea high salinity water mass (ASHSW) from the northern Arabian Sea (Shetye et al., 1990). The consequent strong thermal stratification inhibits any vertical mixing and causes nutrient depletion and lower productivity in the surface layers of the non-eddy regions. Moreover; as there was no freshwater input or sediment discharge from any sources to the open ocean, the sunlight could penetrate deep, where there are enough nutrients to support biological production, resulting in the observed deep chlorophyll maximum.

(a) Primary Productivity $(\mathrm{mgC} / \mathrm{m} 3)$

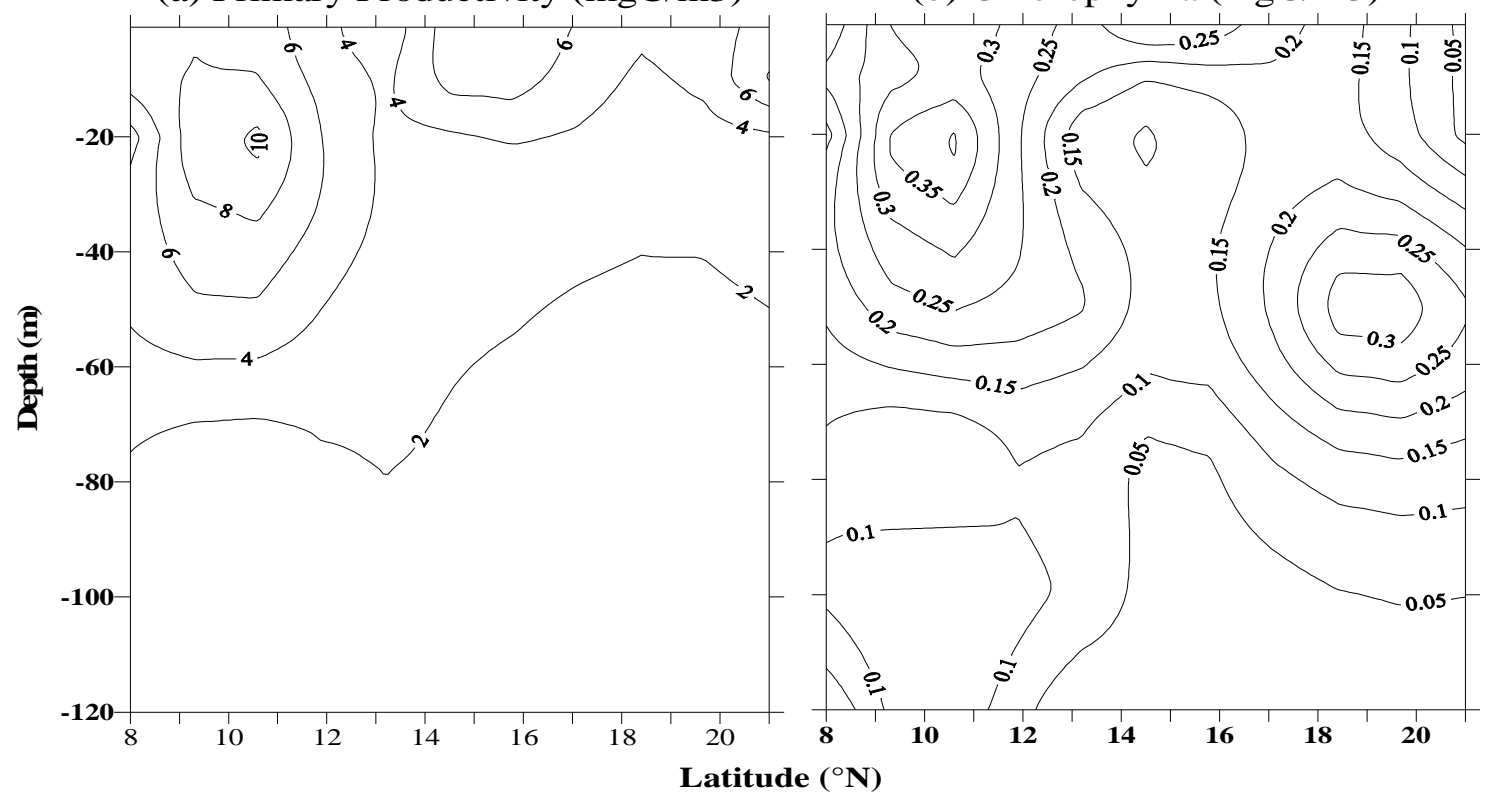

Figure 4. Vertical section of (a) primary productivity $\left(\mathrm{mg} \mathrm{C}^{3}\right)$ and (b) chlorophyll a ( $\mathrm{mg}$ $\left.\mathrm{C} / \mathrm{m}^{3}\right)$ in the upper $120 \mathrm{~m}$ along the open ocean transect of the eastern Arabian Sea 
On an annual scale, in addition to the seasonal upwelling by winds, the magnitude and fate of organic carbon fluxes to the deep Arabian Sea basin is also partially controlled by the regional- to basin-scale mesoscale eddies which are the mediators of biological production during the demise of the summer monsoon. Mesoscale eddies provide a mechanism for export fluxes, through the fertilization of an exhausted surface mixed layer by nutrient pumping and the consequent direct transport of high planktonic biomass downwards out of the surface mixed layer of the Arabian Sea during the monsoons. Indeed, the high export fluxes to the deep Arabian Sea is largely controlled by a dynamic coupling between the particle supply, primary production, sedimentation pathways, biological pump efficiency, and the associated food-web structure (Buesseler, 1998; Buesseler et al., 1998). The magnitude of nutrient inputs associated with mesoscale eddies can have significant role on the biological time scales both for phytoplankton growth and in the development of zooplankton grazing pressure. The effect that mesoscale features have on a resident plankton community will clearly depend upon the gradients in nutrients and phytoplankton initially present and on the intrinsic biological reaction rates. Thus, phytoplankton with a rapid growth rate will benefit from arriving within a patch of nutrient-rich water, possibly at the cost of a previously dominant species that thrived on an ability to do better with low nutrient levels in the long term and which lacks the opportunistic edge (Joseph et al., 2008). A shift in species composition that favors larger diatoms and dinoflagellates or coccolithophorids has significant implications for biogeochemical cycling of materials and hence on the transport of organic carbon fluxes to deeper waters (Bienfang, 1980; Sahayak, 2005). Episodic eddy pumping is largely responsible for significantly enhancing the role of larger diatoms in biogeochemical processes, since these events could account for the rather sporadic coupling between the production and sinking of organic particles in the Arabian Sea (Honjo and Weller, 1997; Buesseler et al., 1998). This coupling and the observed deep chlorophyll maxima suggests that a relatively rapid export of organic carbon fluxes to the deeper layers of the Arabian Sea is mainly derived from the enhanced biological production mediated by eddies in the surface layers. Yet, the nutrient supply mechanism via eddies will be highly stochastic and therefore unlikely to be persistently represented as settling organic matter that is captured by sediment traps at fixed locations. Critically, the eddy-induced pumping would produce an increase in upper ocean nutrient levels - thus stimulating primary production and grazing - a few weeks before an enhanced vertical flux is found in the sediment traps of the Arabian Sea. Diatoms, dinoflagellates and coccolithophorids posses hard, dense opal and calcium carbonate cell walls, which facilitate sinking of senescent cells, or cells that are grazed by herbivorous zooplankton and excreted as fecal pellets. High particle sedimentation rates are attained in the sediment traps of the Arabian Sea by means of rapidly sinking fecal pellets produced by gelatinous macrozooplankton (Haake et al., 1993; Nair et al., 1989). Accordingly, the regional to the basin-wide episodic injections of nutrients to the surface layers associated with mesoscale eddies often increase the rate of biological productivity and subsequently exports higher rate of organic carbon fluxes to the deeper layers in the form of sinking particles as measured by the sediment traps observed in the Arabian Sea (Honjo et al., 1999; Kim et al., 2001; Marra and Barber, 2005; Wiggert et al., 2005). These eddies further laterally advect and diffuse the sinking particle fluxes and convey about a spectacular enhancement of biogenic particle sedimentation in the deep sea sediment traps of the Arabian Sea (Siegel et al., 1990; Honjo et al., 1999). Consequently, a 70\% 
of biogenic sedimentation recorded from the sediment traps of the Arabian Sea is due to the increased production and export largely in response to increased eddy mixing (Haake et al., 1993; Nair et al., 1989; Wiggert et al., 2005). Thus, mesoscale eddies play a critical role in ocean biogeochemistry by increasing the nutrient supply, elevates the primary production, and dominates the efficiency of export fluxes to the deep Arabian Sea waters.

\section{Summary and conclusion}

In summary, like elsewhere, mesoscale eddies may impact primary productivity in the eastern Arabian Sea. Accordingly, the high chlorophyll $a$ concentrations combined with high primary productivity that were observed in the vicinity of the cold-core eddy of the southern region, were associated with nitrate injected into the upper layers due to eddy-induced mixing. The anomalous chlorophyll $a$ structure observed in the eddy region may be due to enhanced vertical entrainment of subsurface nutrients into the euphotic zone resulting from prolonged surface cooling and deep convection from summer storms as the eddy moved away from its area of formation into waters with an overlying colder atmosphere. This might explain why productivity and chlorophyll $a$ in the cold core eddy region were high. Thus, eddy pumping may provide a plausible explanation for the mechanism that mixes nutrients into the euphotic zone and support biological productivity in the open ocean region of the eastern Arabian Sea during southwest monsoon retreat. Hence cold core eddies have a significant role for nutrient entrainment and replenishment. Variations in the physical forcings are likely to cause variations in the supply of nutrients to the euphotic zone and might cause variations in the chlorophyll $a$ and primary productivity of this biologically high productive region. In conclusion, the export fluxes to the deep Arabian Sea is a conundrum and is probably linked with an interplay between the passage of short-term episodic events like eddies, nutrient availability, the intensity of primary production and the rapid response of grazers that are occurring within the euphotic zone. Future work is however to be done to unravel the relevant potential implications of the low oxygen signatures being upwelled, nutrient dynamics and possible phytoplankton speciation within the eddies capable of affecting the deep sea particle fluxes.

Acknowledgements. We are thankful to the Director, National Institute of Oceanography, Goa for providing the facilities for the study. We thank Department of Ocean Development (DOD), New Delhi for the financial support to the Marine Research Living Resources $(M R-L R)$ Assessment Programme funded by Centre for Marine Living Resources and Ecology (CMLRE), Cochin. Rejomon George is deeply indebted to the Department of Science \& Technology (DST), New Delhi, India for the financial assistance for the Fast Track Research Project No. SR/FTP/ES-122/2009.

\section{REFERENCES}

[1] Angel, M.V. (1984): Deep-water biological processes in the north-west region of the Indian Ocean. - Deep-Sea Research 31A: 935-950.

[2] Antoine, D., Andre, J.M., Morel, A. (1996): Oceanic primary production 2. Estimation at global scale from satellite (coastal zone color scanner) chlorophyll. - Global Biogeochemical Cycles 10: 57-69. 
[3] Bhattathiri, P.M.A., Pant, A., Sawant, S., Gauns, M., Matondkar, S.G.P., Mohanraju, R. (1996): Phytoplankton production and chlorophyll distribution in the eastern and central Arabian Sea in 1994-1995. - Current Science 71: 857-862.

[4] Bienfang, P.K. (1980): Phytoplankton sinking rates in oligotrophic waters off Hawaii, USA. - Marine Biology 61: 69-77.

[5] Brock, J.C., Mc Clain, C.R., Luther, M.E. Hay, W.W. (1991): The phytoplankton bloom in the northwestern Arabian Sea during the southwest monsoon of 1979. - Journal of Geophysical Research 96(642): 623-630.

[6] Brock, J.C., Mc Clain, C.R. (1992): Interannual variability in phytoplankton blooms observed in the northwestern Arabian Sea during the southwest monsoon. - Journal of Geophysical Research 97: 733-750.

[7] Bruce, J.G., Johnson, D.R., Kindle, J.C. (1994): Evidence for eddy formation in the eastern Arabian Sea during the northeast monsoon. - Journal of Geophysical Research 99: 7651-7664.

[8] Bruce, J.G., Kindle, J.C., Kantha, L.H., Kerling, J.L., Bailey, J.F. (1998): Recent observations and modeling in the Arabian Sea Laccadive High region. - Journal of Geophysical Research 103: 7593-7600.

[9] Buesseler, K.O. (1998): The decoupling of production and particulate export in the surface ocean. - Global Biogeochemical Cycles 12: 297-310.

[10] Buesseler, K.O., Ball, L., Andrews, J., Benitez-Nelson, C., Belastock, R., Chai, E., Chao, Y. (1998): Upper ocean export of particulate organic carbon in the Arabian Sea derived from thorium-234. - Deep-Sea Research 45: 2461-2488.

[11] Dileepkumar, M., Rajendran, A., Somasundar, D., Haake, B., Jenisch, A., Shuo, Z., Ittekkot, V., Desai, B.N. (1990): Dynamics of dissolved organic carbon in the northwestern Indian Ocean. Marine Chemistry 31: 299-316.

[12] Ediger, D., Tugrul, S., Yilmaz, A. (2005): Vertical profiles of particulate organic matter and its relationship with chlorophyll-a in the upper layer of the NE Mediterranean Sea. Journal of Marine Systems 55: 311-326.

[13] Haake, B., Ittekkot, V., Rixen, T., Ramaswamy, V., Nair, R.R., Curry, W.B. (1993): Seasonality and interannual variability of particle fluxes to the deep Arabian Sea. - Deep Sea Research 40: 1323-1344.

[14] Honjo, S., Weller, R. (1997): Monsoon winds and carbon cycles in the Arabian Sea. Oceanus 40: 24-28.

[15] Honjo, S., Dymond, J., Prell, W., Ittekkot, V. (1999): Monsoon-controlled export fluxes to the interior of the Arabian Sea. - Deep Sea Research 46: 1859-1902.

[16] Ittekkot, V., Haake, B., Bartsch, M., Nair, R.R., Ramaswamy, V. (1992): Organic carbon removal in the sea: The continental connection, - In: Upwelling systems: Evolution Since the early Miocene, C. P. Summerhayes et al. eds., Geological Society of London Special Publication 64: 167-176.

[17] Joseph, T., Shaiju, P., Laluraj, C.M., Balachandran, K.K., Nair, M., Rejomon, G., Nair, K.K.C., Sahayak, S., Prabhakaran, M.P. (2008): Nutrient environment of red tide-infested waters off south-west coast of India. - Environmental Monitoring and Assessment 143: 355-361.

[18] Kim, H.S., Flagg, C.N., Howden, S.D. (2001): Northern Arabian Sea variability from TOPEX/Poseidon altimetry data: an extension of the US JGOFS/ONR shipboard ADCP study. - Deep Sea Research 48: 1069-1096.

[19] King, F.D. (1986): The dependence of primary production in the mixed layer of the Eastern Tropical Pacific on the vertical transport of nitrate. - Deep Sea Research 33: 733754.

[20] Koblentz-Mishke, O.J., Volkovinsky, V.V., Kabanova, J.C. (1970): Plankton primary production of the world ocean. - In: Scientific exploration of the South Pacific, Wooster,W.S. (ed.), National Academy of Sciences, pp. 183-193. 
[21] Krey, J., Babenard, B. (1976): Phytoplankton Production Atlas of the International Indian Ocean Expedition. - Intergovernmental Oceanographic Commission, Paris, p. 70.

[22] Lierheimer, J.L., Banse, K. (2002): Seasonal and interannual variability of phytoplankton pigment in the Laccadive (Lakshadweep) Sea as observed by the Coastal Zone Color Scanner. - Proceedings of the Indian Academy of Sciences 111: 163-185.

[23] Luis, J.A., Kawamura, H. (2004): Air-Sea Interaction, Coastal Circulation and Primary Production in the Eastern Arabian Sea: A Review. - Journal of Oceanography 60: 205218.

[24] Marra, J., Barber, R.T. (2005): Primary productivity in the Arabian Sea: A synthesis of JGOFS data. - Progress in Oceanography 65: 159-175.

[25] Mc Creary, J.P., Kohler, K.E., Hood, R.R., Olson, D.B. (1996): A four-component ecosystem model of biological activity in the Arabian Sea. - Progress in Oceanography 37: 193-240.

[26] Nair, R.R., Ittekkot, V., Managani, S.J., Ramaswamy, V., Haake, B., Degens, E.T., Desai, B.N., Honjo, S. (1989). Increased particle flux to the deep ocean related to monsoons. Nature 338: 749-751.

[27] Platt, T., Harrinson, W.G., Lewis, M.R., Li, K.W., Sathyendranath, S., Smith, R.E., Vezina, A.F. (1989): Biological production of the oceans: the case for a consensus. Marine Ecology Progress Series 52: 77- 88.

[28] Prasannakumar, S., Nuncio, M., Narvekar, J., Kumar, A., Sardesai, S., de Souza, S.N., Gauns, M., Ramaiah, N., Madhupratap, M. (2004): Are eddies nature's trigger to enhance biological productivity in the Bay of Bengal? - Geophysical Research Letters 31: p.7309 doi:10.1029/2003GL019274.

[29] Sahayak, S., Jyothibabu, R., Jayalakshmi, K.J., Habeebrehman, H., Sabu, P., Prabhakaran, M.P., Jasmine, P., Shaiju, P., Rejomon, G., Joseph, T., Nair, K.K.C. (2005): Red tide of Noctiluca miliaris off south of Thiruvananthapuram subsequent to the "stench event' at the southern Kerala coast. - Current Science 89: 1472-143.

[30] Sen Gupta, R., Naqvi, S.W.A. (1984): Chemical oceanography of the Indian Ocean, north of the equator. - Deep Sea Research 31: 671-706.

[31] Shankar, D., Shetye, S.R. (1997): On the dynamics of the Lakshadweep high and low in the southeastern Arabian Sea. - Journal of Geophysical Research 102: 12551-12562.

[32] Shankar, D., Vinayachandran, N.P., Unnikrishnan, A.S. (2002): The monsoon currents in the north Indian Ocean. - Progress in Oceanography 52: 63-120.

[33] Smitha, B.R., Sanjeevan, V.N., Vimalkumar, K.G., Revichandran, C. (2008): On the Upwelling off the Southern Tip and along the West Coast of India. - Journal of Coastal Research 24: 95-102.

[34] Shetye, S.R., Gouveia, A.D., Shenoi, S.S.C., Sundar, D., Michael, G.S., Almeida, A.M., Santanam, K. (1990): Hydrography and circulation of the west coast of India during the southwest monsoon. - Journal of Marine Research 48: 359-378.

[35] Siegel, D.A., Granata, C.T., Michael, E.A., Dickey, T.D. (1990): Mesoscale eddy diffusion, particle sinking, and the interpretation of sediment trap data. - Journal of Geophysical Research 95: 5305-5311.

[36] Strickland, J.D.H., Parsons, T.R. (1972): In a practical handbook of seawater analysis. (second ed.) - Bulletin Fisheries Research Board of Canada 167: p. 310.

[37] U.N. Educational, Scientific and Cultural Organization (UNESCO). (1994): Protocols for the Joint Global Ocean Flux Study (JGOFS) core measurements, Paris, - JGOFS Rep. 19.

[38] Vinayachandran, P.N., Yamagata, T. (1998): Monsoon response of the Sea around Sri Lanka: Generation of thermal domes and anticyclonic vortices. - Journal of Physical Oceanography 28: 1946-1960.

[39] Vinayachandran, P.N., Masumoto, Y., Mikawa, T. and Yamagata, T. (1999). Intrusion of the Southwest Monsoon Current into the Bay of Bengal. - Journal of Geophysical Research 104: 11077-11085. 
[40] Whitney, F.A., Crawford, R.W., Harrison, P.J. (2005): Physical processes that enhance nutrient transport and primary productivity in the coastal and open ocean of the subarctic NE Pacific. - Deep Sea Research 52: 681-706.

[41] Wiggert, J.D., Hood, R.R., Banse, K., Kindle, J.C. (2005): Monsoon-driven biogeochemical processes in the Arabian Sea. - Progress in Oceanography 65: 176-213. 